Terbit online pada laman web jurnal : http://e-journal.sastra-unes.com/index.php/JILP

\begin{tabular}{|c|c|c|}
\hline \multirow[b]{2}{*}{$\begin{array}{c}\text { Fakultas Sastra } \\
\text { Universitas Ekasakti }\end{array}$} & \multicolumn{2}{|c|}{$\begin{array}{c}\text { (JURNAL, ILMIAH LANGUE AND PAROLE) } \\
\text { VOLUME } 2 \text { NOMOR } 2\end{array}$} \\
\hline & $\begin{array}{c}\text { ISSN : 2581-0804 } \\
\text { (Media Cetak) }\end{array}$ & $\begin{array}{c}\text { E-ISSN : 2581-1819 } \\
\text { (Media Online) }\end{array}$ \\
\hline
\end{tabular}

\title{
THE USE OF ADDRESS FORMS RELATED TO SOCIAL FACTORS AND PROXEMIC IN 12 ANGRY MEN MOVIE
}

\author{
Veno Elriyan, Yessy Marzona \\ Fakultas Sastra Universitas Ekasakti \\ *Corresponding Author: Yessy Marzona \\ Universitas Ekasakti \\ yessy.marzona@gmail.com
}

\begin{abstract}
This thesis discusses the use of address forms created in a conversation in a film entitled 12 Angry Men [1957).This study was conducted to look at the forms of address forms used by participants and related to social factors that influence the choice of address form, as well as the relationship between the choice of address forms and the types of proxemics that occurs between participants.

In writing this thesis, the observation method is taken as a method of collecting the data. For method of analyzing the data, the writer uses the content analysis method by analyzing the content of primary data. Technique of collecting the data using qualitative techniques by taking notes in collecting primary data. In the technique of analyzing the data, the writer uses the content analysis technique.

From the 20 data analyzed, it was found that there were three types of address forms present in this movie. The first type is the Title with a percentage of 75 percent. The second type is the Nickname with a percentage of 15 percent. The last type is a combination of some forms with a percentage of 10 percent. The social factors that influence the choice of address forms in this film are due to social status, particular occasion and occupational hierarchy. Whereas in proxemic is dominated by the use of social distance. It can be concluded that the occurrence of variations in the use of address forms can be caused by various social factors, and the use of distance (proxemics) and address forms occur at the same time.
\end{abstract}

Keywords: Address Forms, Social Factors, Proxemics

\section{INTRODUCTION}

(C) 2019Jurnal JILP

The idea of address forms was observed firstly by Brown and Gilman in 1960 (Fasold : 1990). They studied second person pronoun usage in French, German, Italian and Spanish. They proposed that the use of pronoun was governed by power and solidarity. Then, inspired by this study, many sociolinguists are interested in the study of address forms since it correlates to the daily life and culture.

Address form is a way to address someone in interaction. According to Trudgill (1992: 9) "address forms are words and phrases used to address other people in conversation, meeting, letters, etc". We can address the interlocutor by many ways. Wardhaugh (1992:265) says that

Jurnal JILP (Jurnal Ilmiah Langue and Parole) Vol. 2 No. 2 (2019) ISSN : 2581-0804

This work is licensed under a Creative Commons Attribution-NonCommercial 4.0 International License. 
"the ways for addressing can be in the form of Title (T), First Name (FN), Last Name (LN), Nick Name (NN), some combination of these, or by nothing at all". A form of address may be friendly, unfriendly, or neutral; respectful, disrespectful, or comradely. From the way they use address form to show respect, power, solidarity, politeness or self-awareness toward the others. Some factors can influence the use of address form. According to Wardaugh (1992:270) there are some factors such as : the particular occasion, the social status or rank of the other, sex, age, family relationship, occupational hierarchy, transactional status, race, or degree of intimacy. In addition, Holmes (1992:12) said that the variation depends on the participant, setting, topic and function of the talk.

Not only use verbal communication but we also use non-verbal communication to interact with other people. Sometimes we use non-verbal communication to emphasized the message. Non-verbal communication can be shown by eye contact, gesture, facial expression, and personal distance. The study of personal distance can be called as Proxemics. Knapp (1977:182) says that "Proxemics is the study of man's use space and perception of his social and personal distance".

Proxemic describes how people create the distance and space when they are interacting with the others. All of people have a personal distance but it differs from one culture to another culture. "Hall", an anthropologist who developed proxemic theory, divided our personal distance into four : intimate distance, personal distante, social distance and public distance. Address form and Proxemic are the things that cannot be separated in conversation. Because, when two or

\section{RESEARCH METHODS}

In order to do a scientific and wellorganized research, the writer must apply an appropriate method and approach in discussing the data. The writer generally applies three following steps in conducting this research. They are : method of collecting the data, method of analyzing the data, technique of collecting the data, and technique of analyzing the data.

This research used qualitative method. According to Denscombe (2007:248), qualitative research is closely related to the use of words to make a larger unit like texts as the subject of more people involve in discussion, they will make physical distance automatically. For example when a student discusses about a topic in class situation with the lecturer, automatically they will make a physical distance that is different from when they interact with friends or their lovers.

In studying address form, the writer decides to choose a movie as the primary source of data. In the movie, the writer sees there are many interactions conducted by the participants and it also represents the human being's behaviours. Beside that, the movie contains spoken language that reflects the address usage in society. And also the writer chooses a movie as the source of the data because from the movie, the writer can see the Proxemic that is used by the character to analyze the relationship between address form and proxemics. Here, the writer chooses 12 Angry Men Movie.

The writer chooses this movie because this movie was one of the best movies at that era which led Fonda to get an Oscar trophy. Furthermore based on its contents, this movie tells us much more about the democracy of American court, different people with different point of view, psychological talks, and also philosophical of the language. So, the writer found many address forms used in this movie by the characters in their interactions, the characters can be distinguished by the social status, relationship, power and solidarity.

By studying address forms, we can know the social information about identity, gender, age, status, because address forms are used to reflect the social identity and social relationship in a community.

analysis. He adds that qualitative research is different from quantitative research which pays attention to numbers as the subject of analysis.

Qualitative research allows the researcher to give more description to the subject being analyzed. As stated by Vanderstoep and Johnson (2009:8) it gives clear description and narration about the subject of analysis. The research also use some fix number to support the description of the data. This research is aimed to describe the language that is used in the movie entitle 12 Angry Men. This research focused on the use of 
address form in the language that is used by the character in the movie. Specifically, it focused on the types of address form, functions and the types of proxemics that appear by characters.

\section{Method of Collecting the Data}

In collecting the data, the writer uses observasional method proposed by Denscombe. According to Denscombe (2007:286), data in qualitative research is taken from words or images that are used in the subject that being analyzed. This research used the data in the form of sentence, clause of word spoken by the character in 12 Angry Men movie. The context of data were utterance and conversations that were taken from the dialogue in the movie.

\section{Method of Analyzing the Data}

The technique employed in this research was content analysis. According to Denscombe (2007:236), content analysis is a method that can used in any text to analyze the content of the data. He breaks down the content analysis procedure into six procedures. The first procedure is choosing an appropriate sample of text in the data that the researcher had collected. Second, create a smaller component unit from the data. Third, develop relevant categories to analyze the data. Fourth, create coding technique that is in line with the categories. Fifth, from the coding it is needed to count the frequency of the data occurring. The last procedure is analyzing the data in terms of frequency and the relationship with other units.

\section{Technique of Collecting the Data}

The writer chooses the dialogues in the movie as the source of data. The dialogue of the movie is found at an authorized subtitle-provider website entitled subscene.com. The dialogues then put into a table of the data. Later, the dialogue is read one by one carefully to find the in-demand data. In this research, the data were collected and classified by observing the spoken language as the data. The spoken language was taken from the audio and visual image in the movie. The steps in collecting data in this research were presented below :

1) The researcher observed the movie by replaying the movie, transcribing the transcription based on the film and crosschecking the script with the movie.

2) The researcher gave mark to every dialogues containing address forms spoken by the character in the movie.

\section{Technique of Analyzing the Data}

Finally, in this research, the technique of data analysis used was content analysis. The analysis was related to the address forms that were used by the character. The result of data collecting was examined by the following steps :

1) The data taken from the 12 Angry Men movie were analyzed.

2) The data were classified based on the research question and put into the data sheet.

3) Each datum which had been classified in the data sheet was analyzed based on the research question.

4) The data were interpreted to answer the three research questions.

5) The findings were explained in content analysis description.

6) Finally, the findings were concluded.

\section{RESULTS AND DISCUSSION}

As mentioned in the first chapter of this research, this research has the main goal in revealing the types, functions of address forms, social factors that affect the character, and the types of proxemics usage by the characters. This chapter provides the result of this research. It consists of two parts, discussion and findings.

The data discussion show the table of occurrence of the types of address forms uttered by characters of the 12 Angry Men Movie, the

functions of those address forms and also the social factor which affect participants in using those address forms. Meanwhile, the findings presents the deep analysis of this research which is based on the research objectives.

This section display the data that founded, and group it according to research questions ; types of address forms, the functions of the address forms, the social factors that affect 
participants in using certain types of address forms, and the types of proxemics that appear when the participants use the certain address forms.

In the below section, the researcher tries to present the discussion of this research in the form of tables.

Table 1. Table the analysis of address forms, social factors and proxemics in the data

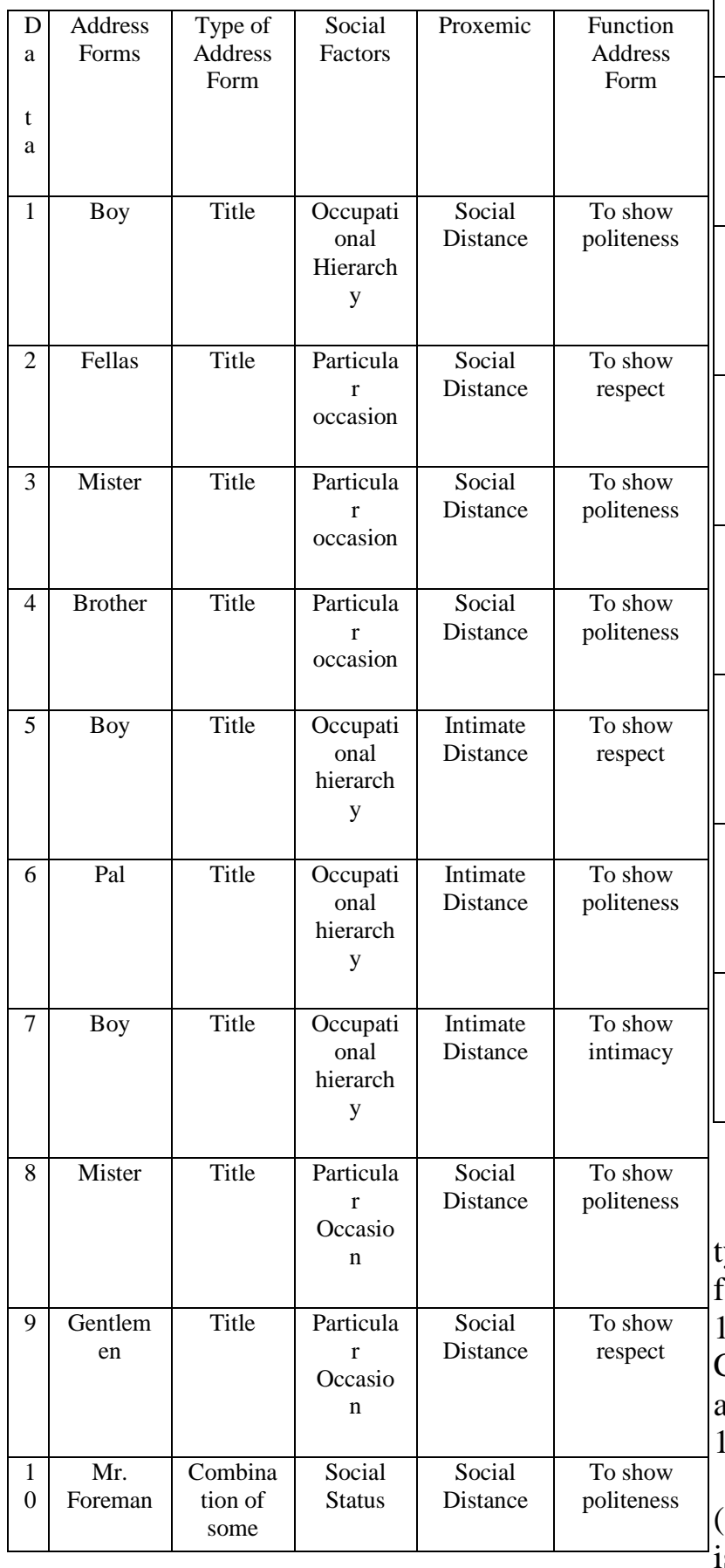

From the taken data, the writer found three types of address form used in the movie. The first type is Title (data $1,2,3,4,5,6,7,8,9,11$, $14,15,16,18,19$ and 20). The second type is Combination of some forms (datum 10 and 12), and the last type is Nickname (data 12, 13 and 17) .

The most used address form is Title type $(75 \%)$. The use of this variation of address form is reasonable. According to the major story, this

Jurnal JILP (Jurnal Ilmiah Langue and Parole) Vol. 2 No. 2 (2019) ISSN : 2581-0804

This work is licensed under a Creative Commons Attribution-NonCommercial 4.0 International License. 
movie narrates about twelve unknown men discussed a criminal case to decide a young man's life. Because of the plain distance between them and also its formal situation, they must use appropriate language and utterance on delivering their opinion. It is anethic code that must be obeyed as civilized people in the democratic country. In this case, respect between the men is obviously existed.

However, the language is still a human product. It can be separated from the sociocultural and emotional side. The movie also displays some variations that indicates impoliteness and disrespectful through the dialogue because of socio-cultural and emotional influence. The writer found four form that refer to negative-side of language. They are Mr. Reasonable Doubt (data 12), smart-guy (data 13), killer (data 14), and loudmouth (data 17). All of these forms are used by its speaker for mocking their hearer.

And regarding to Proxemic, as intimacy indicator based on distance, the writer finds 'Social Distance' as the dominant type. The use, then, is followed by 'Intimate Distance' as the second dominant. And then, 'Personal Distance' as the third dominant. Not all proxemics types are applied. Public Distance is not found in the data.

This section is different from the previous section of this chapter which only answers the research question by presenting tables and giving description. This section uses deeper explanations from each point of the findings. Moreover, the examples for each phenomenon are also described.

Types of Address Forms Performed by Characters in 12 Angry Men Movie.

\section{A. Title}

1. [05.26] Boy, you'd think they'd at least air- condition these places.

The identified address form in the utterance above is 'boy'. The address form 'boy' in this case can classify as title. If it is seen on its form, the 'boy' is a general type. In contrast with boy in a kinship, it must be based on blood relationship or marriage. However, in this case the participants are unknown each other. They have no way relation at all. So, it concludes to a general one.
The function of the form 'boy' here can be identified as no kinship at all. As said before, they have no relation each other even for blood or marriage. The usage of the form 'boy' here happens because the speaker in this case is older than his hearer. It means, the term 'boy' uses its alternative function rather than its natural role.

2. [17.40] Now, fellas, please. Let's go in order here, huh?

This utterance still takes place in the discussion room. The participants are several men among the twelve jurymen. Specifically, the speaker is one of the jury who protest the way of discussion runs. He notifies his speakers to keep on the rule of the discussion. He intends to maintain the well-managed discussion because everybody will get their own turn. However, the speaker here is not the jury leader.

The identified address form in the utterance above is 'fellas'. The word 'fellas' is the plural form of fellow. It means, the speaker refers to several man (more than one especially) in this expression. The address form 'fellas' in this case can classify as title. If it is seen on its form, the term 'fellas' is general type. General type indicates high tense of formality because the obvious distance between the participants.

The function of the form 'fellas' in the expression above, is for neutral situation. It means the speaker still keep respecting each other. It also indicates equivalent power and more solidarity between the participants. Plain distance over the participants creates awkwardness between their conversations. The speaker here can not use his power because he is as powerless as his hearer. Because of this consideration, the speaker decides to choose the term 'fellas' over than other choices.

3. [22.36] Listen, Mister, listen. I, uh... I've live in a slum all my life.

This line still goes on in the meeting room. The participants are numerous men within the twelve jurymen. In particular, the speaker is one of the jury who complain about the other's jury perspective about a slum area. He warns the speakers to be aware with his personal opinion. He intends to make clear that the slum life is not as bad as people think. He could say about it because he has lived in a slum side over years.

The finding of the address form in the utterance above is 'mister'. The word 'mister' is used to call up someone whose name is not 
known. It means, the speaker clearly know the person he points out, but does not know the name. The address form 'mister' in this case can classify as title. Based on the context, the form 'mister' is general type. General type signifies high level of formality because the obvious distance between the participants.

4. [33.17] Brother, you really are something.

This utterance still takes place in the discussion room. The participants are the juror number three and five. In particular, the speaker is one of the jury who accuses the other jury for using personal feeling in changing his vote. He feels annoyed because the man changes his mind so fast after some hear some melancholic statements. In fact, the man who is accused by the jury number three, does not change his vote.

The identified address form in the utterance above is 'brother'. The word 'brother' mainly uses for sibling or blood relationship. However, in this case the participants do not know each other. The address form 'brother' in this case can classify as title. If it is seen on its form, the term 'brother' is general type. General type indicates high tense of formality because the obvious distance between the participants. In this context, the use of the term is suitable.

5. [36.52] Boy, you got it. Believe me.

This utterance takes place in a toilet, but still in the discussion room. The participants are the jury number seven (speaker) and eight (hearer). In particular, the speaker declares his admiration to his hearer about how the way he makes people believe in his words. He suspect his hearer is a salesman because his extraordinary skill. However, the man is just an architect.

The identified address form in the utterance above is 'boy'. The word 'boy' commonly uses as a friendly informal reference to a grown man. However, in this case the participants are not friend. The address form 'boy' in this case can classify as title. If it is seen on its form, the term 'boy' is general type. General type indicates high tense of formality because the obvious distance between the participants. In this context, the use of the term is suitable.

6. [37.48] This kid is guilty, pal.
This utterance still happens in toilet room. The participants are similar too, the jury number seven and eight. The speaker thinks his hearer is in wrong way. He tries to convince him to change his vote again. He warns his hearer to stop wasting time in this discussion. The kid is guilty, as plain as a nose in the face. However, the hearer rejects his opinion and continues to discuss the case until it is over.

The identified address form in the utterance above is 'pal'. The word 'pal' usually applies for close friend. However, in this case, the speaker and participant do not know each other. The address form 'pal' in this case can be classified as title. If it is seen on its form, the 'pal' is a general type.

7. [38.23] Phew! Boy, what a murderous day.

This utterance shows up in a toilet room. The participants are the jury number six (speaker) and eight (hearer). They do direct conversation for the first time. The speaker utters his opinion about the case. He feels tired and exhausted because of long discussion in a hot day. He also states that the group of man there are not nice. However, the hearer just replies his sigh calmly.

The identified address form in the utterance above is 'boy'. The word 'boy' usually applies for informal friendly greeting or younger person. However, in this case, the speaker and hearer are not friend each other. The address form 'boy' in this case can be classified as title. If it is seen on its form, the 'boy' is a general type.

8. [43.50] You ought to have more respect, mister.

This utterance occurs in a discussion room after short break. The participant are the jury number six (speaker) and four (hearer). The current situation at that time is really bad. The speaker warns his hearer seriously. He did it after hearing the jury number four mocks the oldest jury's opinion there. He approaches his hearer to keep respecting the old man's ideas and stop insulting him with sarcasm. Then, the speaker gives a chance for the old man to deliver his idea about the case.

The identified address form in the utterance above is 'mister'. The word 'mister' commonly applies for addressing a man. It can be older, younger or non-specific direction. The 
address form 'mister' in this case can classify as title. If it is seen on its form, the term 'mister' is general type. General type indicates high tense of formality because the obvious distance between the participants. In this context, the use of the term is suitable.

9. [45.10] Gentlement, that's a very sad thing, to be nothing.

The oldest jury is the speaker in this time. The setting is in discussion room. Here, he tries to delivers his opinion about an old man. The rest of the jury is the hearer in this time. The oldest jury conveys his opinion about the probability of error by an old man witness. This is a one-way communication.

The identified address form in the utterance above is 'gentleman'. The word 'gentleman' mostly employs for formal situation. In this case, the speaker addresses all of his hearers with that term. The address form 'gentleman' in this case can classify as title. If it is seen on its form, the term 'gentleman' is general type. General type indicates high tense of formality because the obvious distance between the participants. In this context, the use of the term is suitable.

$$
\text { that? }
$$

10. [51.30] Boy, How do you like

This line occurs in the discussion room. The speaker is jury number ten and the hearers are the rest of the jurymen. The speaker feels infuriating with the earlier statement launched by jury number eight. He perceives the jury number eight has twisted the fact. He cannot believe the man like this can be a jury in that room. The statement above clearly represents his frustration about that matter.

The finding of the address form in the utterance above is 'boy'. The word 'boy' is used to call up a younger male or grown man. In this case, the speaker points out several grown men in that room. The address form 'boy' in this case can classify as title. Based on the context, the term 'boy' is general type. General type signifies high level of formality because the obvious distance between the participants. However, in this line, the informality is truer than formality. The level of informality becomes intense analogously with the development of the discussion.
11. [58.30] Brother, I've seen all kinds of dishonesty in my day, but this little display takes the cake.

This line happens in discussion room. The speaker is jury number three and the hearer is the rest of the jurymen. The speaker starts to perform his anger in this time. He thinks the prior demonstration and other's jury assumption is a big joke. He calls the jury to think properly than use their bleeding heart to judge this case. In the midst of his frustration, he says the line above.

The identified address form in the utterance above is 'brother'. The word 'brother' mainly uses for sibling or blood relationship. However, in this case the participants do not know each other. The address form 'brother' in this case can classify as title. If it is seen on its form, the term 'brother' is general type. General type indicates high tense of formality because the obvious distance between the participants.

12. [59.32] Is there anything wrong, gentlement? I heard some noise.

This line takes place in a discussion room. The speaker is a gentleman from the court and the hearer is the chief of the jury, Mr. Foreman. The speaker comes to the discussion room after hearing some noises. He asks Mr. Foreman about what really happen. Mr. Foreman tells him that there is nothing to worry about. Then Mr. Foreman gives the man the diagram before he left.

The address form found in the speech above is 'gentleman'. The word 'gentleman' mostly applies for formal matter. In this case, the speaker addresses his hearer with that term. The address form 'gentleman' in this case can classify as title. If it is seen on its form, the term 'gentleman' is general type. General type indicates high tense of formality because the obvious distance between the participants.

$$
\text { 13. [01.12.27] Oh boy, look at the }
$$
rain.

This line takes place in a silent situation. After a long discussion and dispute, the jurymen take a break for resting themselves. They prevent themselves to speak for a moment. As soon as that, the rain is falling down. The jury number twelve then breaks the silence with his words. He muses into a rainfall and imagines how cool the weather outside rather than inside here. 
The address form found in the utterance above is 'boy'. The word 'boy' is used to call up a younger male or grown man. In this case, the speaker points out several grown men in that room. The address term 'boy' in this case can classify as title. Based on the context, the term 'boy' is general type. General type signifies high level of formality because the obvious distance between the participants. However, in this line, the informality is truer than formality. The level of informality becomes intense analogously with the time of the discussion.

14. [1.14.27] Boy. I hate these things.

This line occurs in a middle of stabbing demonstration. The speaker is jury number five and the hearer is the jury number eight. The speaker takes a look into a knife that used by the young boy on killing his father. He amazes with the model of the knife because its extraordinary appearance. He suggests that the knife is a switchblade. Then later he describes how to use it properly in the front of jurymen. He said that line in the middle of his amazement.

The identified address form in the line above is 'boy'. The word 'boy' is used to call up a younger male or grown man. In this case, the speaker points out jury number eight as his addressee. The address form 'boy' in this case can classify as title. Based on the context, the form 'boy' is general type. General type signifies high level of formality because the obvious distance between the participants. However, in this line, the informality is truer than formality. The level of informality becomes intense analogously with the development of the discussion.

buddy.

$$
\text { 15. [1.16.28] Now, listen }
$$

This line occurs in middle of discussion. The speaker is jury number seven and the hearer is jury number eleven. They involve in a little argument. Jury number eleven discontents with jury number seven's attitude. He changes his vote carelessly without any solid reason. Then the jury number eleven approaches and warns him to do his job responsibly.

The address form found in the utterance above is 'buddy'. The word 'buddy' usually applies for close friend especially one who often acts as a companion. However, in this case, the speaker and participant do not know each other.
The address form 'buddy' in this case can be classified as title. If it is seen on its form, the 'buddy' is a general type.

\section{B. First Name}

First Name never appeared in the data.

C. Last Name

Last Name never appeared in the data.

D. Nickname

1. [56.24] Listen, smart guy.

The finding of the address form in the utterance above is 'smart guy'. The word 'smart guy' consists of two parts, smart and guy. Smart means demonstrating intelligence and guy for informal term for youth or man. The address form 'smart guy' in this case can classify as nickname. Nickname type signifies high level of informality because it shows intimacy. However, in this case, the intimacy is negative.

\section{2. [57.06] Okay. Okay, killer.}

This line occurs in the midst of exhibition of a proof. The jury number eight tries to recreate a display about an old man's testimony. In the process of demonstration, jury number seven seems lost of focus and disrespect the case. He makes a whistling sound. Then, jury number two approaches and tries to stop the man. The jury number seven feels annoyed and mocks him with that form.

The identified address form in the utterance above is 'killer'. The word 'killer' means the causal agent resulting in death. However, in this case it does not represent what really happens in reality. They all are the legal man. The address term 'killer' in this case can be classified as nickname. If it is seen on its form, the 'killer' is a negative type.

3. [1.04.33] Now, listen. I don't think you have any right... Loudmouth

The line above occurs in a small group of discussion between three jurymen. The speaker is jury number two and the hearer is jury number ten. The jury number ten feels annoyed with the vote changed decision. He accuses the jury number two is mixed up and cannot think clearly. The jury number two says it is his right. He tries to explain to his hearer but he just passes out. Finally, he utters that loathly line.

The identified address form in the utterance above is 'loudmouth'. The word 
'loudmouth' means a person who causes trouble by speaking indiscreetly. It is similar with bigmouth or blabbermouth. The address form 'loudmouth' in this case can be classified as nickname. If it is seen on its form, the 'loudmouth' is a negative type.

E. Combination of some forms

1. [47.08] Mr. Foreman, I'd like to change my vote to not guilty.

The identified address form in the utterance above is 'Mr. Foreman'. The phrase 'Mr. Foreman' consists of two part, Mister and Foreman. The address term 'Mr. Foreman' in this case can classify as combination some forms. The form 'mister' is a title and form 'Foreman' is last name. This combination implies a degree of difference between the speaker and hearer.

2. [53.01] Now, what about this, Mr. Reasonable Doubt?

This line occurs in the middle of discussion. The speaker is the jury number three and the hearer is the jury number ten. The speaker feels tired of the vote result. He then approaches the jury number ten who suddenly change his vote. He questions what the meaning of reasonable doubt for him is. Then he mocks his hearer with that form.

The identified address form in the utterance above is 'Mr. Reasonable Doubt'. The phrase 'Mr. Reasonable Doubt' consists of two part, Mister and Reasonable Doubt. The address form 'Mr. Reasonable Doubt' in this case can classify as combination some forms. The form mister is a title and form reasonable doubt is nickname.

Functions of Address Forms Performed by the Character in 12 Angry Men movie.

A. To show intimacy

The use of address forms in communication is not simply as the way to address other people. It contains functions or purposes and it is influenced by some factors. One of the functions of address terms is to show intimacy.The examples of address form to show intimacy performed by characters are as follows:

[38.23] Phew! Boy, what a murderous day. This utterance shows up in a toilet room. The participants are the jury number six (speaker) and eight (hearer). They do direct conversation for the first time. The speaker utters his opinion about the case. He feels tired and exhausted because of long discussion in a hot day. He also states that the group of man there are not nice. However, the hearer just replies his sigh calmly.

The function of the form 'boy' here can be identified to show intimacy. Based on the context, the participants do not recognize each other for making a fair result. The practice of the form 'boy' here happens for a reason. The speaker wants to make a friendly situation. It means, the form 'boy' uses its alternative function rather than its natural role.

B. To show politeness

The functions of address forms are various. One of the functions is to show politeness/power differential. The examples of this phenomenon are as follows:

[22.36] Listen, Mister, listen. I, uh... I've live in a slum all my life.

The function of the form 'mister' here is to show politeness. The speaker has hidden motif behind his expression. He tends to warn the speaker to keep his words. He perceives the statement he heard before is far from the truth he believes in. However, he shares similar portion of power in this case. In result, he just puts some offensive emphasizes in his expression without break the barrier of respect. mister.

[43.50] You ought to have more respect,

This utterance occurs in a discussion room after short break. The participant are the jury number six (speaker) and four (hearer). The current situation at that time is really bad. The speaker warns his hearer seriously. He did it after hearing the jury number four mocks the oldest jury's opinion there. He approaches his hearer to keep respecting the old man's ideas and stop insulting him with sarcasm. Then, the speaker gives a chance for the old man to deliver his idea about the case.

The function of the form 'mister' in the expression above is to show politeness. It means the speaker has intended meaning behind that term. He will to caution his speaker to pay a respect. He perceives the statement he heard before is intolerably nasty. However, he shares 
similar portion of power in this case. In result, he just puts some offensive emphasizes in his expression without break the border of respect.

\section{[56.24] Listen, smart guy.}

This line takes place in a demonstration of a testimony. The speaker is jury number ten and the hearer is jury number five. They involve in a battle of argument. The hearer says that the lawyer never thinks about this demonstration. Then, the speaker mocks his opinion and calls him with that form.

The function of the form 'smart guy' here is to show politeness. The speaker has implicit motif behind this expression. Based on its structure, it indicates positive purpose. Meanwhile, in this context, it turns into negative one. The speaker here wants to scorn his hearer with this term. The speaker claims his hearer so clever with his argument before. He chooses the paradox style in term to use the alternative role of the term 'smart guy'. By saying the contrary with the fact, it means the speaker offends his hearer.

\section{To show respect}

Another function of address form is to show respect. The examples of this phenomenon can be seen in the below section:

[45.10] Gentlement, that's a very sad thing, to be nothing.

The function of the form 'gentleman' in the expression above is to show respect. It means the speaker has a motif behind that form. The speaker wants to persuade his hearers to be logical and objective. The form 'gentleman' implies a civilized, well-educated and matures enough for man category. So, his argument can be adopted perfectly by his hearer due to 'gentleman' categorical. The form 'gentleman' also indicates a high level of respect and less solidarity because its nature of formality.

Social Factors that Affect the Characters in a Movie Entitled 12 Angry Men Using Certain Types of Address Forms.

The use of address forms in communication is not simply a way to address other people. There are some factors that influence the speaker to choose certain types of address forms toward the addressee.There are many factors that affect the choice of address form,they are Particular Occasion, Social Status, Sex, Age, Family Relationship, Occupational Hierarchy, Race and Degree of Intimacy. Based on the table of data, only three types of social factors founded, and describe in explanation below :

\section{A. Particular Occasion}

People tend to differently address someone else in different place where they communicate. For example, people who involved in a court trial session will use formal language to honor other people even suspects. They will address one another usually with Title. There are some examples of the use of address forms that influenced by Particular Occasion performed by participants as follows:

[17.40] Now, fellas, please. Let's go in order here, huh?

[22.36] Listen, Mister, listen. I, uh... I've live in a slum all my life.

[33.17] Brother, you really are something.

[43.50] You ought to have more respect, mister.

[45.10] Gentlement, that's a very sad thing, to be nothing.

\section{B. Social Status}

There are some factors that influence people to use certain types of address form in their communication. One of the factors that can influence people is Social Status. For example, the use of First Name in addressing someone indicates intimacy between the speaker and the addressee. However, such type of address forms also indicates inequality power between them. The superior will receive Title/Last Name when they are addressed while the inferior will received First Name. Another factor is the use of Last Name in addressing other people. The use of Last Name in addressing other people also employed by the superior to address the inferior. The examples of the use of address forms that influenced by Social Status are follows:

[47.08] Mr. Foreman, I'd like to change my vote to not guilty.

\section{Occupational Hierarchy}

The choice of the types of address form will also determine by the circumstance around 
the place where people work. Occupational Hierarchy greatly influence in the way people address other people in their place of work. The examples of the use of address forms that influenced by Occupational Hierarchy are follows :

[05.26] Boy, you'd think they'd at least air-condition these places.

[36.52] Boy, you got it. Believe me.

[37.48] This kid is guilty, pal.

[38.23] Phew! Boy, what a murderous day.

[51.30] Boy, How do you like that?

[53.01] Now, what about this, Mr. Reasonable Doubt?

[56.24] Listen, smart guy.

[57.06] Okay. Okay, killer.

[58.30] Brother, I've seen all kinds of dishonesty in my day, but this little display takes the cake.

[1.04.33] Now, listen. I don't think you have any right... Loudmouth

[01.12.27] Oh boy, look at the rain.

[1.14.27] Boy. I hate these things.

[1.16.28] Now, listen buddy.

D. Age

E. Family Relationship

F. Degree of intimacy

Age, Family relationship and Degree of intimacy was a social factor that never appeared in the data.

Types of Proxemics that appear when the participants use the certain address forms.

A. Intimate distance

Intimate distance varies from direct physical contact with another person, to a distance of six of eighteen inches. The examples of the use of Intimate distance performed by participants as follows:

[36.52] Boy, you got it. Believe me.

This utterance takes place in a toilet, but still in the discussion room. The participants are the jury number seven (speaker) and eight (hearer). He use physical contact when addresses the hearer, it can be grouped as intimate distance.

[37.48] This kid is guilty, pal.
This utterance still happens in toilet room. The participants are similar too, the jury number seven and eight. The speaker thinks his hearer is in wrong way. He tries to convince him to change his vote again. He warns his hearer to stop wasting time in this discussion.

[38.23] Phew! Boy, what a murderous day.

The participants are the jury number six (speaker) and eight (hearer). They do direct conversation for the first time. The speaker utters his opinion about the case.

B. Personal Distance

This distance into a close and a far phase. The close phase is one and a half to two and a half feet. The far phase is two and a half to four feet. The close phase permits one person to touch another while the far phase of personal distance does not permit this. Where a person stands within this range shows the closeness of relationship. The examples of the use of Intimate distance performed by participants as follows :

[1.04.33] Now, listen. I don't think you have any right... Loudmouth

The line above occurs in a small group of discussion between three jurymen. The speaker is jury number two and the hearer is jury number ten.

\section{Social Distance}

Hall also divides social distance into two phases ; a close phase and far phase. The close social distance is four to seven feet. The far phase is seven to twelve feet. This distance is common using in business meeting, classrooms and impersonal social affairs. The distance is generated while there is a physical barrier between the participants. Some physical barriers such as desks, tables and counters usually make people keep this distance. The examples of the use of Social Distance performed by participants as follows :

[43.50] You ought to have more respect, mister.

This utterance occurs in a discussion room after short break. The participant are the jury number six (speaker) and four (hearer). The current situation at that time is really bad. The 
speaker warns his hearer seriously. He did it after hearing the jury number four mocks the oldest jury's opinion there.

[45.10] Gentlement, that's a very sad thing, to be nothing.

The oldest jury is the speaker in this time. The setting is in discussion room. Here, he tries to delivers his opinion about an old man. The rest of the jury is the hearer in this time. The oldest jury conveys his opinion about the probability of error by an old man witness. This is a one-way communication.

\section{CONCLUSION}

By researcher address forms, the result is to know the social information about identity, gender, age, status because address forms are used to reflect the social identity and social relationship in community. People do not use one way but use many ways to address someone. The choice of address form that is addressed by the speakers expresses their feeling or attitude toward their interlocutor, such as the feeling of respect, politeness, solidarity, etc. however, by using appropriate address forms, the speaker will make the hearer feeling well and not be insulted, hurt or offended. Consequently, there will be good communication between speakers and the message of the talk can be received effectively.

Furthermore, most of people do not realize that Proxemic appears automatically when the people interact. Sometimes, the participants use distance to emphasize the intimacy or social degree between them. In the formal situation, the relationship between address form and Proxemic is more visible than in informal situation. It caused by a situation that in formal situation they must respect the identity, status and age of the interlocutor. But in informal situation, they can break that rule. Just depends on the degree of intimacy between the participants. Address forms and Proxemic are the things that cannot be separated in conversation. Because, when two or more people involve in discussion, they will make physical distance automatically.

From the analysis of the research above, some suggestions can be given to the following parties:
[47.08] Mr. Foreman, I'd like to change my vote to not guilty.

This statement occurs in a discussion room. The participants are the jury number five (speaker) and one (hearer). The speaker delivers his decision to change his side become not guilty. He reaches out his reasonable doubt after hearing the probability of the witness lies in his testimony. Then, he calls for a vote, not guilty.

D. Public Distance

Public Distance never appeared in the data.

\section{To Linguistics Students}

It is important to give advance study on the use of address forms in certain community, especially English community. It is because English language broadly use in all parts of the world and becomes international language so the understanding of English language is needed. The problem will arise if people who do not belong to certain community try to understand the language used by the community, especially in the application of address forms. In fact, every language that exists in different society or community has its own characteristic in using address forms.

\section{To Other Researcher}

The finding on the use of address forms in this research, especially in the types, functions, and social factors of address form are influenced by context of communication. For example, where the conversation takes place or to whom a speaker talks to. Place or circumstance can greatly influence the use of certain types of address form. A formal occasion usually also requires formal language during conversation.

The writer's limited capability and source to conduct further study on the address forms may be countered by having other researcher to conduct other deeper investigations in the similar field, especially the investigation in the types, functions, and purposes of the address form. This research is only preliminary study for any other advance analysis in the future. 


\section{Bibliography}

[1]Aitchison, Jean.2003. Linguistics. London: The McGraw-Hill Companies.

[2]Denscombe, Martyn. 2007. The Good Research Guide: For Small-Scale Social Research Projects. 3th Edition. New York: Open University Press.

[3]Esmae'li, S.2011. Terms of address Usage : The Case of Iranian Spouse. Retrieved from https://.ijhssnet.com/journals/vol_1_no_9 special_issues/20.pdf. [Accessed 8Juni 2019].

[4]Fasold, Ralph. 1990. The Sociolinguistics of Language. USA : Blackwell Publisher Inc.

[5]Hall, Edward T. 1991. A first Look at Communication Theory. From:http://www.afirstlook.com/arrive/pro xemics.cfm/sorce $=$ archther. $\quad$ [Accessed 14April 2019].

[6]Holmes, Janet. 1992. An Introduction to Sociolinguistics. London and New York: Longman

[7]Holtgraves, M Thomas. 2002. Language as Social Actions: Social Psychology and Language Use. London: Lawrence Erlbum Associates, Inc.

[8]Hudson, R. A. 1989. Sociolinguistics. Cambridge University Press.
[9]Hymes, Dell. 1972. Direction in Sociolinguistics: The Ethnography of Communication. Holt, Rinehart and WinstonInc.

[10]Knapp, Mark L. 1972. Nonverbal Communication in Human Interaction. Holt Rinehart and Winston. Inc. USA

[11]Meyer, Carles F. 2009. Introducing English Linguistics. UK: Cambridge University Press.

[12]Sali A. Tagliamonte. 2006. Analysing Sociolinguistic Variation. Cambridge: Cambridge University Press.

[13] Stockwell, Peter. 2007. Language and Linguistics: The Key Concepts (Second Edition). USA: Routledge.

[14]Vandestoep, Scott W and Johnson, Deirdre D. 2009. Research Method for Everyday Life. San Fransisco: Jossey-Bass.

[15]Wardaugh, Ronald. 1992. An Introduction to Sociolinguistics. Second edition. USA:Blackwell Publisher.

[16]Wardhaugh, Ronald. 2006. An Introduction to Sociolinguistics: fifth Edition. UK: Blackwell Publishing.

[17]Xiaomei, Y. 2010. Address forms of English: Rules and Variation. http://academymypublisher.com2findex .php2.pdf.pdf. [Accessed 14April 2019]. 